\title{
Production of Proteolytic Enzymes by a Keratin-Degrading Aspergillus niger
}

\author{
Fernanda Cortez Lopes, ${ }^{1}$ Lucas André Dedavid e Silva, ${ }^{2}$ Deise Michele Tichota, ${ }^{1}$ \\ Daniel Joner Daroit, ${ }^{1}$ Renata Voltolini Velho, ${ }^{1}$ Jamile Queiroz Pereira, ${ }^{1}$ \\ Ana Paula Folmer Corrêa, ${ }^{1}$ and Adriano Brandelli ${ }^{1}$ \\ ${ }^{1}$ Laboratório de Bioquímica e Microbiologia Aplicada, Departamento de Ciência de Alimentos (ICTA), \\ Universidade Federal do Rio Grande do Sul, Avenida Bento Gonçalves 9500, 91501-970 Porto Alegre, RS, Brazil \\ ${ }^{2}$ Laboratório de Peptídeos e Enzimas Proteoliticas, Centro de Biotecnologia, Universidade Federal do Rio Grande do Sul, \\ Avenida Bento Gonçalves 9500, 91501-970 Porto Alegre, RS, Brazil
}

Correspondence should be addressed to Adriano Brandelli, abrand@ufrgs.br

Received 6 May 2011; Accepted 9 July 2011

Academic Editor: Alane Beatriz Vermelho

Copyright (C) 2011 Fernanda Cortez Lopes et al. This is an open access article distributed under the Creative Commons Attribution License, which permits unrestricted use, distribution, and reproduction in any medium, provided the original work is properly cited.

A fungal isolate with capability to grow in keratinous substrate as only source of carbon and nitrogen was identified as Aspergillus niger using the sequencing of the ITS region of the rDNA. This strain produced a slightly acid keratinase and an acid protease during cultivation in feather meal. The peak of keratinolytic activity occurred in $48 \mathrm{~h}$ and the maximum proteolytic activity in $96 \mathrm{~h}$. These enzymes were partly characterized as serine protease and aspartic protease, respectively. The effects of feather meal concentration and initial $\mathrm{pH}$ on enzyme production were evaluated using a central composite design combined with response surface methodology. The optimal conditions were determined as $\mathrm{pH} 5.0$ for protease and 7.8 for keratinase and $20 \mathrm{~g} / \mathrm{L}$ of feather meal, showing that both models were predictive. Production of keratinases by A. niger is a less-exploited field that might represent a novel and promising biotechnological application for this microorganism.

\section{Introduction}

Aspergillus niger is one of the most important microorganisms in biotechnology. It has been already used to produce extracellular enzymes such as glucose oxidase, pectinase, $\alpha$ amylase and glucoamylase, organic acids, and recombinant proteins. In addition, $A$. niger is used for biotransformations and waste treatment [1-3]. Among the various enzymes produced by the fungus are included proteases. The major extracellular proteolytic activities in A. niger appear to be due to acid proteases [4]. Acid proteases [E.C.3.4.23] are endopeptidases that depend on aspartic acid residues for their catalytic activity and show maximal activity at low $\mathrm{pH}$. These enzymes offer a variety of applications in the food, beverage industry, and medicine [5].

Keratin is a fibrous protein that occurs in vertebrates and exerts protective and structural functions. It is the major component of feathers, wool, scales, hair, stratum corneum, horns, scalps, and nails [6]. Keratin is insoluble and presents high mechanic resistance, as well as recalcitrance to common proteolytic enzymes like pepsin, trypsin, and papain [7]. This resistance is because of the tight folding of protein chain in $\alpha$-helix ( $\alpha$-keratin) and $\beta$-sheets $(\beta$-keratin) in a super-coiled polypeptide chain, kept by strong association by disulfide bonds [8, 9]. Keratinases [EC 3.4.21/24/99.11] are specific proteases that display the capability of keratin degradation. These enzymes are gaining importance in the last years, with many applications associated with hydrolysis of keratinous substrates, mainly byproducts of agroindustrial processes [10]. Generally, keratinases have optimum $\mathrm{pH}$ from neutral to alkaline [11].

The utilization of agroindustrial wastes may represent an added value to the industry and meets the increasing awareness for energy conserving and recycling [12]. This fact stimulates the investigation for alternatives to convert keratinous waste into valuable products [10]. One example 
is the poultry industry that generates huge amount of byproducts, which may represent a potential environmental hazard if they are incorrectly destined or processed. The processing and/or treatment of slaughterhouse waste have been one of the great concerns of poultry industry, mainly because of the restrictions on environmental questions [13].

In this work, the production of proteolytic enzymes by a new keratinolytic strain of $A$. niger was investigated. The enzyme activity was partially characterized, and a culture medium based on keratinous substrate was selected, evaluating the influence of growth substrate concentration and medium $\mathrm{pH}$ on the production of proteolytic enzymes.

\section{Materials and Methods}

2.1. Microorganism. The fungus used in this work was isolated from citrus waste and belongs to the collection of Laboratório de Bioquímica e Microbiologia Aplicada (Porto Alegre, Brazil). The strain was maintained on Potato Dextrose Agar (PDA; Himedia, Mumbai, India) slants with mineral oil at $4{ }^{\circ} \mathrm{C}$ and subcultured periodically.

2.2. DNA Isolation. Genomic DNA was extracted according to the method described by Casali et al. [14] with modifications. A culture of 5 days in $5 \mathrm{~mL}$ of brain heart infusion broth (BHI; Oxoid, Hampshire, England) was vortexed, and the whole mycelia was transferred to a microtube containing $0.5 \mathrm{~mL}$ of TENTS ( $2 \%$ Triton X-100; $1 \mathrm{mM}$ EDTA; $200 \mathrm{mM}$ $\mathrm{NaCl} ; 10 \mathrm{mM}$ Tris- $\mathrm{HCl}$ Buffer $\mathrm{pH}$ 7.5; 1\% SDS) and $0.2 \mathrm{~mL}$ of glass beads $(200 \mu \mathrm{m})$. This mixture was vortexed for 4 cycles of 2 min alternating with ice bath of $30 \mathrm{~s}$. After $0.5 \mathrm{~mL}$ of chloroform was added, it was vortexed for $30 \mathrm{~s}$ and centrifuged for $15 \mathrm{~min}$ at $13,000 \times \mathrm{g}$. The aqueous phase was washed again with chloroform. The nucleic acids were precipitated with $2 \mathrm{vol}$ of absolute ethanol containing $200 \mathrm{mM} \mathrm{NaCl}$. The microtubes were incubated at $-20^{\circ} \mathrm{C}$ overnight and centrifuged for $15 \mathrm{~min}$ at $13,000 \times \mathrm{g}$. The precipitate was washed with $0.2 \mathrm{~mL}$ of $70 \%(\mathrm{v} / \mathrm{v})$ ethanol. After ethanol evaporation, the precipitate was resuspended in $20 \mu \mathrm{L}$ MilliQ water. The extracted DNA was observed on $0.9 \%$ agarose gels.

2.3. PCR Assay. The fungus was identified using the partial sequencing of the intergenic region of the rDNA. An ITS region was selected as a target sequence for PCR using universal primers ITS 1 ( $5^{\prime}$-TCCGTAGGTGAACCTGCGG$\left.3^{\prime}\right)$ as a forward primer and ITS $4\left(5^{\prime}\right.$-TCCTCCGCTTTATTGATATGC- $\left.3^{\prime}\right)$ as a reverse primer. A PCR using the thermocycler (Eppendorf, Hamburg, Germany) was performed with the following parameters: an initial denaturation of $5 \mathrm{~min}$ at $95^{\circ} \mathrm{C}, 30$ cycles of $30 \mathrm{~s}$ at $95^{\circ} \mathrm{C}$ for denaturation, $30 \mathrm{~s}$ at $46^{\circ} \mathrm{C}$ for annealing, $80 \mathrm{~s}$ at $72^{\circ} \mathrm{C}$ for extension, and a final extension of $7 \mathrm{~min}$ at $72^{\circ} \mathrm{C}$, according to Horisawa et al. [15] with modifications. All PCR products were stored at $-20^{\circ} \mathrm{C}$ until analyzed. Aliquots of PCR products were examined after electrophoresis on $0.9 \%$ agarose gels.

2.4. DNA Sequencing. PCR products were sequenced in the ACTGene Laboratory (Centro de Biotecnologia, UFRGS,
Porto Alegre, Brazil) using the automatic sequencer ABIPRISM 3100 Genetic Analyzer armed with $50 \mathrm{~cm}$ capillaries and POP6 polymer (Applied Biosystems). Sequencing data were collected using the software Data Collection v1.0.1 (Applied Biosystems). The sequences obtained were edited using the software BioEdit (1997-2005 Tom Hall) and then submitted to the BLAST algorithm to retrieve for homologous sequences in GenBank (National Center for Biotechnology Information (http://www.ncbi.nlm.nih.gov/)).

2.5. Phylogenetic Analyses. The sequence data were obtained from Genbank submissions and were used for comparisons with the $599 \mathrm{bp}$ from our isolate. The sequences were aligned using software ClustalX version 2.0 [16], and the phylogenetic analyses were performed using MEGA 4.0 [17] for neighbor-joining and bootstrap analysis. A. fumigatus and A. ellipticus were used as outgroups. Bootstrap values were generated by 1,000 replications.

2.6. Conidia Suspension. A. niger was routinely cultivated on PDA plates at $30^{\circ} \mathrm{C}$ until sporulation. After that, the conidia was suspended with sterile distilled water and collected with a Pasteur's capillary. The material was centrifuged at $10,000 \times \mathrm{g}$ for $10 \mathrm{~min}$. The supernatant was discarded, and the spores were suspended again in distilled water. The conidia concentration was determined with a Neubauer's chamber. The concentration used in the experiments was $10^{6}$ conidia/mL [18].

2.7. Keratinous Growth Substrates and Culture Media. Five keratinous substrates were used as carbon and nitrogen sources for fungal growth: human hair, pig hair, feather meal, chicken feathers, and bovine horn. Human hair was previously washed with distilled water. Feathers were washed with $0.1 \%(\mathrm{v} / \mathrm{v})$ Triton X-100 and distilled water and then cut into small pieces to enhance the contact surface. The other substrates were not submitted to pretreatments.

The keratinous substrates were used in the concentration of $10 \mathrm{~g} / \mathrm{L}$ in an aqueous solution. The microorganism was cultivated in Erlenmeyer flasks $(250 \mathrm{~mL})$ containing $50 \mathrm{~mL}$ of medium, for $120 \mathrm{~h}$ at $30^{\circ} \mathrm{C}$, in a rotary shaker (Marconi, Piracicaba, Brazil) at $120 \mathrm{rpm}$. Aseptic samples were collected each $24 \mathrm{~h}$ and filtered through Whatman filter $\mathrm{n}^{\circ} 1$. The filtrate was used for the enzyme assays.

The medium that provided the higher proteolytic and keratinolytic activity was selected, and then the optimum $\mathrm{pH}$ was determined. The buffers used were glycine- $\mathrm{HCl}(\mathrm{pH} 2.5)$, citrate ( $\mathrm{pH} 3.5-5.5)$, and phosphate $(\mathrm{pH} 6.5-8.5)$, all in the concentration $25 \mathrm{mM}$. The utilization of this $\mathrm{pH} 2.5$ and 3.5 buffers to protease was not possible because this $\mathrm{pH}$ caused azocasein precipitation. The composition analysis of feather meal was developed according to AOAC [19].

2.8. Enzymatic Activity on Azocasein. The proteolytic activity was determined using azocasein (Sigma, Steinheim, Germany) as substrate. The assay mixture contained $100 \mu \mathrm{L}$ of $25 \mathrm{mM}$ citrate buffer $\mathrm{pH} 4.5,100 \mu \mathrm{L}$ of enzyme sample, and $200 \mu \mathrm{L}$ of $20 \mathrm{mg}$ azocasein/mL in water. A blank tube was 
prepared with the immediate addition of $800 \mu \mathrm{L}$ of $20 \%$ $(\mathrm{w} / \mathrm{v})$ trichloroacetic acid. Then, the tubes were incubated for 15 minutes at $50^{\circ} \mathrm{C}$. After incubation, $800 \mu \mathrm{L}$ of TCA were added to stop the reaction. The tubes were centrifuged for $10 \mathrm{~min}$ at $10,000 \times \mathrm{g}$. The activity was estimated spectrophotometrically by reading the absorbance at $400 \mathrm{~nm}$. In this assay, one enzyme unit was expressed as the amount of enzyme that caused an increase of 0.1 in the absorbance at $400 \mathrm{~nm}$ per hour [20]. The assays were performed in triplicate.

2.9. Enzymatic Activity on Azokeratin. Azokeratin was synthesized as described by Riffel et al. [21]. The assay was conducted for $1 \mathrm{~h}$ at $50^{\circ} \mathrm{C}$ by incubating $100 \mu \mathrm{L}$ of enzyme sample, and $500 \mu \mathrm{L}$ of a $20 \mathrm{mg}$ azokeratin/mL suspension in $25 \mathrm{mM}$ citrate buffer, $\mathrm{pH}$ 6.5. The reaction was stopped by adding $800 \mu \mathrm{L}$ of $20 \%$ (w/v) TCA solution. The controls were prepared by adding the TCA solution prior to the enzyme. The tubes were centrifuged $(10,000 \times \mathrm{g}$ for $10 \mathrm{~min})$, and activity was calculated from the increase in absorbance at $440 \mathrm{~nm}$. One enzyme unit was expressed as the amount of enzyme that caused an increase of 0.1 in the absorbance at $440 \mathrm{~nm}$ per hour. The assays were performed in triplicate.

2.10. Zymography. The samples of $24,48,72,96$, and $120 \mathrm{~h}$ of cultivation, previously lyophilized and concentrated 10 times, were submitted to electrophoresis on $12 \%$ polyacrylamide gels containing gelatin $(1 \mathrm{mg} / \mathrm{mL})$. After electrophoresis, gels were washed twice with citrate buffer ( $25 \mathrm{mM}, \mathrm{pH} 4.5)$ or phosphate buffer $(25 \mathrm{mM}, \mathrm{pH} 6.5)$ containing 2.5\% (v/v) Triton X-100 for $30 \mathrm{~min}$, and then with the same buffer without detergent for $45 \mathrm{~min}$. After $12 \mathrm{~h}$ of incubation at $30^{\circ} \mathrm{C}$, gels were stained with Coomassie Brilliant Blue R-250 during $2 \mathrm{~h}$ and then destained. Protease bands appeared as clear zones on a blue background due to gelatin hydrolysis [22].

2.11. Characterization Using Protease Inhibitors. Culture supernatants corresponding to peaks of enzymatic activity ( $48 \mathrm{~h}$ for keratinolytic activity and $96 \mathrm{~h}$ for proteolytic activity) were characterized using the protease inhibitors EDTA and $o$-phenanthroline (for metalloproteases), PMSF (for serine protease), pepstatin (for aspartic protease), and iodoacetamide (for cysteine protease). Each inhibitor was preincubated with enzyme extracts for $10 \mathrm{~min}$ at room temperature before assaying for keratinase or protease activity.

2.12. Central Composite Design and Response Surface Methodology. The influence of the keratinous substrate concentration and the initial medium $\mathrm{pH}$ on the production of protease and keratinase was evaluated using a $2^{2}$ experimental model with 4 replicates of the central point, resulting in 12 experiments plus axial points. In the statistical model, the coded variables correspond to feather meal concentration $\left(X_{1}\right)$ and initial $\mathrm{pH}\left(X_{2}\right)$, which are the independent variables; the enzymatic activity $(Y)$ is the dependent variable, and $b_{\mathrm{i}}, b_{\mathrm{ii}}$, and $b_{\mathrm{ij}}$ represent model parameters. The model is demonstrated as follows:

$$
Y=b_{0}+b_{1} X_{1}+b_{2} X_{2}+b_{12} X_{1} X_{2}+b_{11} X_{1}^{2}+b_{22} X_{2}^{2} .
$$

The software Statistica version 6.0 (Statsoft Inc., Tulsa, Okla, USA) was used in the regression analysis of experimental results. The quality of fit of the first-order model equation was expressed by the coefficient of determination $R^{2}$, and its statistical significance was determined by F-test (Fischer's FTest).

The production medium $(50 \mathrm{~mL}$ in $250 \mathrm{~mL}$ Erlenmeyer flask) was inoculated as described above and incubated for 48 and $96 \mathrm{~h}$. To adjust the initial $\mathrm{pH}$, media were prepared with the following buffers: $100 \mathrm{mM}$ glycine- $\mathrm{HCl}(\mathrm{pH} 2.2)$; $100 \mathrm{mM}$ citrate (pH 3.0 and $\mathrm{pH} 5.0$ ); $100 \mathrm{mM}$ phosphate buffer ( $\mathrm{pH} 7.0$ and $\mathrm{pH} 7.8$ ).

The existence of a correlation between the predicted and the experimental values justifies the model validity [23]. Initially, substrate concentration and initial $\mathrm{pH}$ points were chosen, and for these points, the predicted enzyme activities were calculated using the generated equation. For model validation, these activity values were then compared with enzyme activities obtained in actual experiments.

\section{Results and Discussion}

3.1. Identification of the Fungus. The fungus was identified as Aspergillus niger using molecular tools. A sequence of 599 bp showed $97 \%$ identity with $A$. niger. The phenotypic features are according to the results obtained in the molecular identification, since the micro- and macromorphology (Figures 1(a) and 1(b)) show similarities to those described to Aspergillus niger [24]. A phylogenetic tree was developed based on the alignment of the sequences (Figure 1(c)). Giraud et al. [25] reported that A. awamori was not a separate species within the $A$. niger aggregate. Besides, the species $A$. foetidus, based on $\beta$-tubulin analysis, is considered synonyms to $A$. niger $[26,27]$.

According to Schuster et al. [2], the name A. niger is predated by the names Aspergillus phoenicis and Aspergillus ficuum, and it is accepted that these three taxa are all conspecific, as implied by most molecular studies, the latter two taxa would have nomenclatural priority. Since these latter two names are nowadays rarely used, it was proposed at the Second International Workshop on Penicillium and Aspergillus that the name A. niger has to be conserved and A. phoenicis and A. ficuum have to be rejected. This purpose is justified mainly because of the major economic importance of $A$. niger.

3.2. Selection of Culture Medium. Due to the record of acid protease production by $A$. niger, the production of these proteases during the cultivation $(120 \mathrm{~h})$ using different keratinous sources was first investigated. The proteolytic activities observed on different culture media are shown in Figure 2(a). It is possible to observe that the substrate feather meal induced the higher production of proteolytic enzymes $(10.27 \mathrm{U} / \mathrm{mL})$ after $96 \mathrm{~h}$ of culture. The probable 


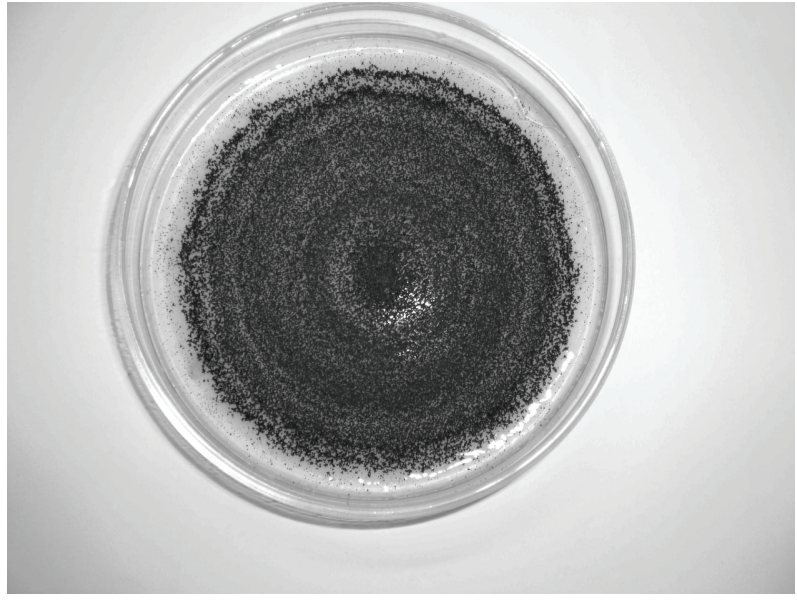

(a)

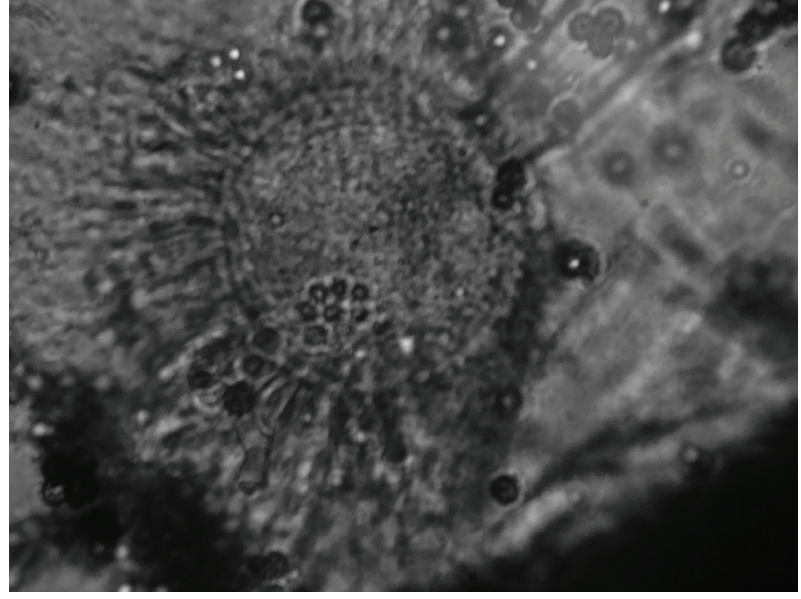

(b)

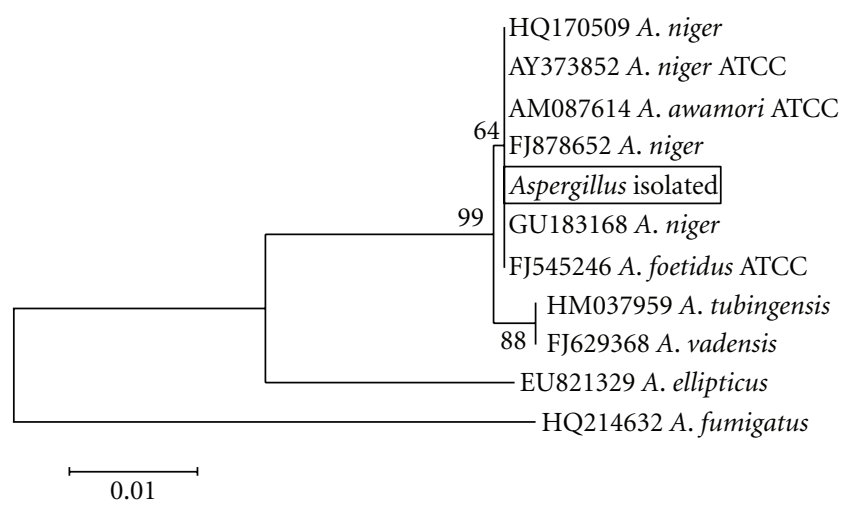

(c)

Figure 1: (a) Macromorphology of A. niger on PDA. (b) Micromorphology of A. niger using optic microscope (1000x). (c) The neighborjoining tree inferred from the partial sequence of the ITS region data set using Mega 4.0 according to Jukes-Cantor Modell. Bootstrap values from 1000 replications are indicated by the nodes.

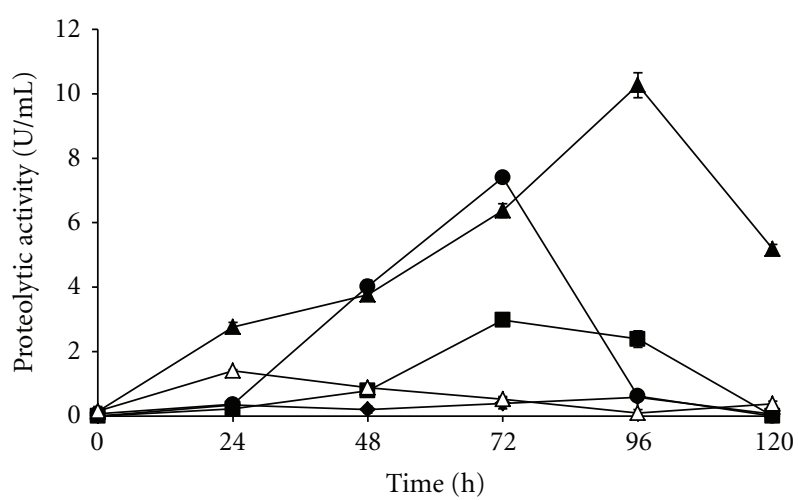

(a)

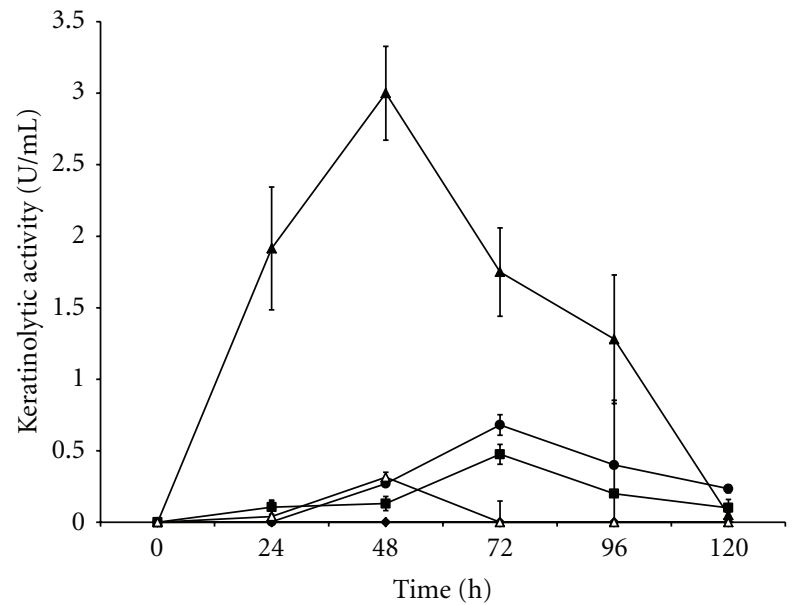

(b)

Figure 2: (a) Production of proteolytic activity and (b) production of keratinolytic activity by A. niger growing on different keratinous substrates $(10 \mathrm{~g} / \mathrm{L}) .(\boldsymbol{\square})$ Bovine horn, $(\triangle)$ chicken feathers, $(\boldsymbol{\Delta})$ feather meal, $(\diamond)$ human hair, and $(\bullet)$ pig hair. 


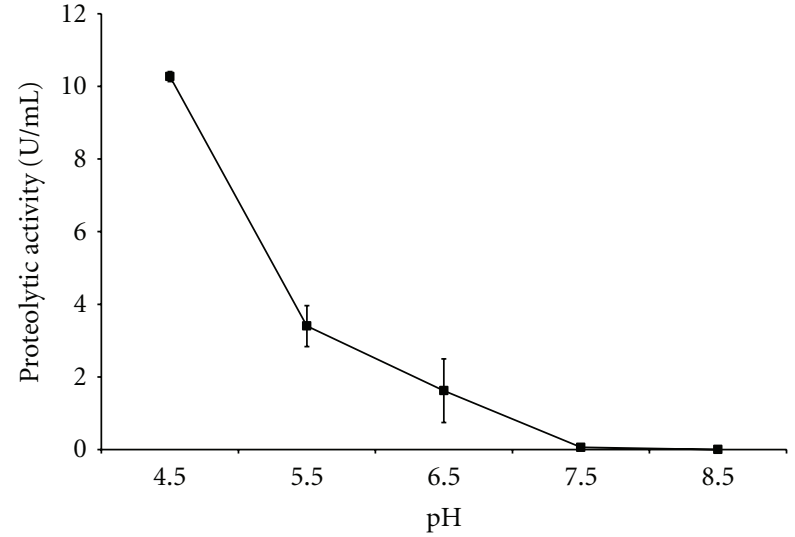

(a)

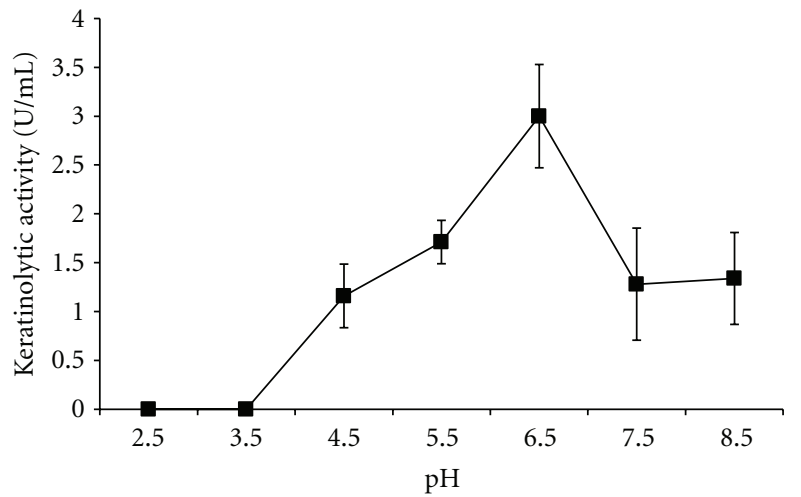

(b)

FIgURE 3: (a) Proteolytic activity of a 96-hour culture and (b) keratinolytic activity of a 48-hour culture of $A$. niger growing on $10 \mathrm{~g} / \mathrm{L}$ feather meal at different $\mathrm{pH}(2.5-8.5)$.

reason could be the higher availability of keratin in feather meal in comparison to the other keratinous materials, mainly because of the thermal and mechanical treatment suffered by this substrate. The process consists in the treatment of feathers, which are pressure cooked in a steam-heated batch cooker at about $207-690 \mathrm{kPa}$, with a moisture content about $60-70 \%$, for about $30-60 \mathrm{~min}$. This permits the hydrolysis and causes the feathers to break up into a final meal [28]. This product contains a high content of crude protein, ranging between 78 and 92\%, being this protein mostly keratin [29]. These values of protein are consistent with the values found in the compositional analysis of the feather meal used in this study (protein $83.7 \mathrm{~g} / 100 \mathrm{~g}$; ash $2.0 \mathrm{~g} / 100 \mathrm{~g}$, fat $4.4 \mathrm{~g} / 100 \mathrm{~g}$ ).

Since A. niger was capable of using keratin as the only source of carbon and nitrogen, the production of keratinases was then evaluated (Figure 2(b)). The samples collected at $24,48,72,96$, and $120 \mathrm{~h}$ were used to determine the peak of keratinolytic activity and the optimum $\mathrm{pH}$. The feather meal substrate also induced the higher keratinolytic activity. The peak of keratinolytic activity occurred in $48 \mathrm{~h}$ of cultivation, and the optimum $\mathrm{pH}$ was 6.5. The keratinolytic activity in this condition was $3.0 \mathrm{U} / \mathrm{mL}$ (Figure 3(b)). Reports on keratinolytic activity of $A$. niger are scarce. The keratinolytic potential of A. niger was described by Anbu et al. [30]. Other keratinolytic species belonging to the genus Aspergillus were Aspergillus fumigatus and Aspergillus oryzae [31]. Besides, keratinases generally have optimum $\mathrm{pH}$ ranging neutral to alkaline [11,31].

From the different cultivation times required for maximal production of keratinase ( $48 \mathrm{~h}$ ) and protease ( $96 \mathrm{~h}$ ) by A. niger (Figure 4), a possible mechanism of feather meal utilization by this strain could be suggested. The probable mechanism of the feather meal degradation could be described as the synergistic activity of both keratinase, which hydrolyzes keratin, a more refractory protein to render polypeptides of less complexity that could be substrate for other protease(s). Moreover, the maximal activity of these enzymes over the time interval analyzed in this study suggests

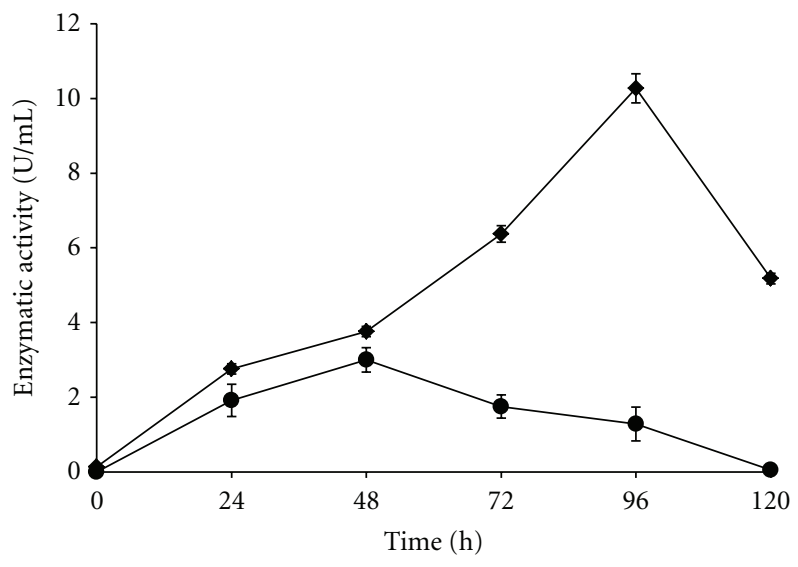

FIGURE 4: Enzymatic activity of protease $(\bullet)$ and keratinase $(\bullet)$ during the 120-hour culture. The assay was performed in the optimum $\mathrm{pH}$ of each enzyme.

that keratinase would be the first to act, followed by other proteolytic enzymes.

3.3. Partial Characterization of Crude Enzymes. To characterize the proteolytic enzymes present in the crude extract, protease inhibitors were used to assay the samples obtained at 48 and $96 \mathrm{~h}$. The proteolytic activity was only inhibited in the presence of pepstatin (Table 1), suggesting an aspartic protease. This is in agreement with the optimum $\mathrm{pH}$ of 4.5 (Figure 3(a)), since acidic $\mathrm{pH}$ values are characteristic of aspartic proteases. Siala et al. [32] reported the purification of an aspartic protease produced by A. niger I1 with optimum $\mathrm{pH} 3.0$, and another study described the production of acid proteases along the growth phases of $A$. niger NRRL 1785 in a five-day cultivation period. The fungus produced a maximum proteolytic activity in $96 \mathrm{~h}$ of culture, and the protease was characterized as an aspartic protease with optimum $\mathrm{pH} 4.0$ [33]. These results are in good agreement with those found in the present study. 
TABLE 1: Characterization of proteolytic and keratinolytic activity using protease inhibitors.

\begin{tabular}{lccc}
\hline & & \multicolumn{2}{c}{ Residual activity $(\%)$} \\
Inhibitor & Concentration & Proteolytic & Keratinolytic \\
\hline None & - & 100 & 100 \\
EDTA & $5 \mathrm{mM}$ & 83 & 176 \\
PMSF & $5 \mathrm{mM}$ & 99 & 58 \\
$1,10-$ & $1 \mathrm{mM}$ & 107 & 145 \\
phenantroline & $5 \mu \mathrm{M}$ & 18 & 100 \\
Pepstatin & $100 \mu \mathrm{M}$ & 89 & 92 \\
Iodoacetamide & & &
\end{tabular}

TABLE 2: Experimental design and results of the $2^{2}$ factorial design.

\begin{tabular}{lcccc}
\hline Run & $\begin{array}{c}X_{1} \\
\left(\begin{array}{c}\text { concentration, } \\
\mathrm{g} / \mathrm{L})\end{array}\right.\end{array}$ & $X_{2}(\mathrm{pH})$ & $\begin{array}{c}Y_{1} \\
\text { (proteolytic } \\
\text { activity } \\
\mathrm{U} / \mathrm{mL})\end{array}$ & $\begin{array}{c}Y_{2} \\
\text { (keratinolytic } \\
\text { activity } \\
\mathrm{U} / \mathrm{mL})\end{array}$ \\
\hline 1 & $-1(10)$ & $-1(3)$ & 2.25 & 0 \\
2 & $-1(10)$ & $+1(7)$ & 0.38 & 1.19 \\
3 & $+1(30)$ & $-1(3)$ & 3.69 & 0.29 \\
4 & $+1(30)$ & $+1(7)$ & 4.32 & 1.22 \\
5 & $0(20)$ & $0(5)$ & 10.87 & 0.54 \\
6 & $0(20)$ & $0(5)$ & 10.36 & 0.84 \\
7 & $0(20)$ & $0(5)$ & 12.03 & 0.75 \\
8 & $0(20)$ & $0(5)$ & 10.80 & 0.68 \\
9 & $0(20)$ & -1.41 & 4.17 & 0.52 \\
& & $(2.20)$ & & \\
10 & $0(20)$ & +1.41 & 1.12 & 1.73 \\
11 & $-1.41(6)$ & $0(5)$ & 3.73 & 0.55 \\
12 & $+1.41(34)$ & $0(5)$ & 11.77 & 0.20 \\
\hline
\end{tabular}

TABLE 3: Main effects and interaction analysis for protease production by $A$. niger growing on feather meal.

\begin{tabular}{|c|c|c|c|c|}
\hline Factors & $\begin{array}{c}\text { Effect } \\
\text { protease }\end{array}$ & $\begin{array}{c}\text { Standard } \\
\text { error }\end{array}$ & $t$ value & $P$ value \\
\hline Medium & 11.02078 & 0.355983 & 30.9588 & $0.000074^{*}$ \\
\hline $\begin{array}{l}\text { Feather } \\
\text { meal }(L)\end{array}$ & 4.19157 & 0.504191 & 8.3135 & $0.003647^{*}$ \\
\hline $\begin{array}{l}\text { Feather } \\
\text { meal }(Q)\end{array}$ & -4.54622 & 0.565214 & -8.0434 & $0.004013^{*}$ \\
\hline $\mathrm{pH}(L)$ & -1.39211 & 0.504191 & -2.7611 & $0.070089^{*}$ \\
\hline $\mathrm{pH}(Q)$ & -9.68345 & 0.565214 & -17.1324 & $0.000433^{*}$ \\
\hline $\begin{array}{l}\text { Feather } \\
\text { meal } \times \mathrm{pH}\end{array}$ & 1.25000 & 0.711972 & 1.7557 & 0.177405 \\
\hline
\end{tabular}

$R^{2}=0.90$.

* Significant factors, $P<0.1$.

Regarding the keratinolytic activity, the inhibition was observed using PMSF, resulting in a residual activity of $58 \%$. Most of the microbial keratinases are alkaline or neutral proteases showing optima $\mathrm{pH}$ ranging from 7.5 to 9.0. However, some enzymes are optimally active outside

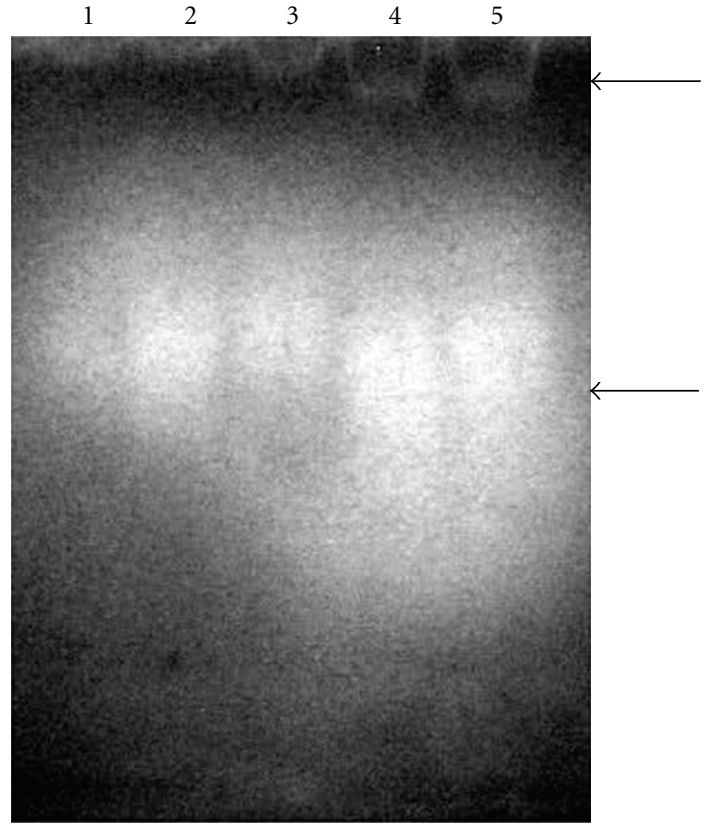

FIGURE 5: Zymogram analysis of (1) 24, (2) 48, (3) 72, (4) 96, and (5) 120-hour cultures supernatants of $A$. niger using citrate buffer $\mathrm{pH} 4.5$.

this range, even at extreme alkalophilic $\mathrm{pH}$ or at slightly acidic pH [11, 31]. Keratinases mostly belong to the class of serine or metalloproteases irrespective of the microorganism. Therefore, PMSF, EDTA, and 1,10-phenantroline are potential inhibitors of these enzymes [11]. In this study, the keratinolytic enzyme showed a neutral $\mathrm{pH}$ optimum $(\mathrm{pH}$ 6.5) and a serine protease character. The keratinases of the genus Aspergillus reported in the literature are a serine protease with optimal $\mathrm{pH}$ varying between 6.5 and 9.0 for $A$. fumigatus [34] and a metalloprotease produced by $A$. oryzae with optimum $\mathrm{pH} 8.0$ [35].

The zymogram revealed two bands, indicating the presence of two proteases (Figure 5). The same activity pattern was observed in the gels incubated in different buffers (data not shown).

3.4. Response Surface Methodology. The experimental conditions and the results of RSM are presented in Table 2. In this study, setting the keratinous substrate (feather meal) and initial $\mathrm{pH}$ as variables, the higher keratinolytic activity was $1.73 \mathrm{U} / \mathrm{mL}$ with $20 \mathrm{~g} / \mathrm{L}$ feather meal and $\mathrm{pH} \mathrm{7.8}$, and the proteolytic activity was $12.03 \mathrm{U} / \mathrm{mL}$ using $20 \mathrm{~g} / \mathrm{L}$ of feather meal and $\mathrm{pH}$ 5.0.

Using the software Statistica 6.0, it was possible to analyze the effect of the independent variables on enzyme production with confidence level of $90 \%$ and $R^{2}$ of 0.90 for protease and $95 \%$ and $R^{2}$ of 0.93 for keratinase (Tables 3 and 4 , resp.). Deviation from the central points $(20 \mathrm{~g}$ feather meal/L and $\mathrm{pH}$ 5.0) usually resulted in less protease production. The linear effect of feather meal concentration was the most expressive variable for protease production, increasing the enzymatic activity in $4.19 \mathrm{U} / \mathrm{mL}$ (Table 3 ), but was not 


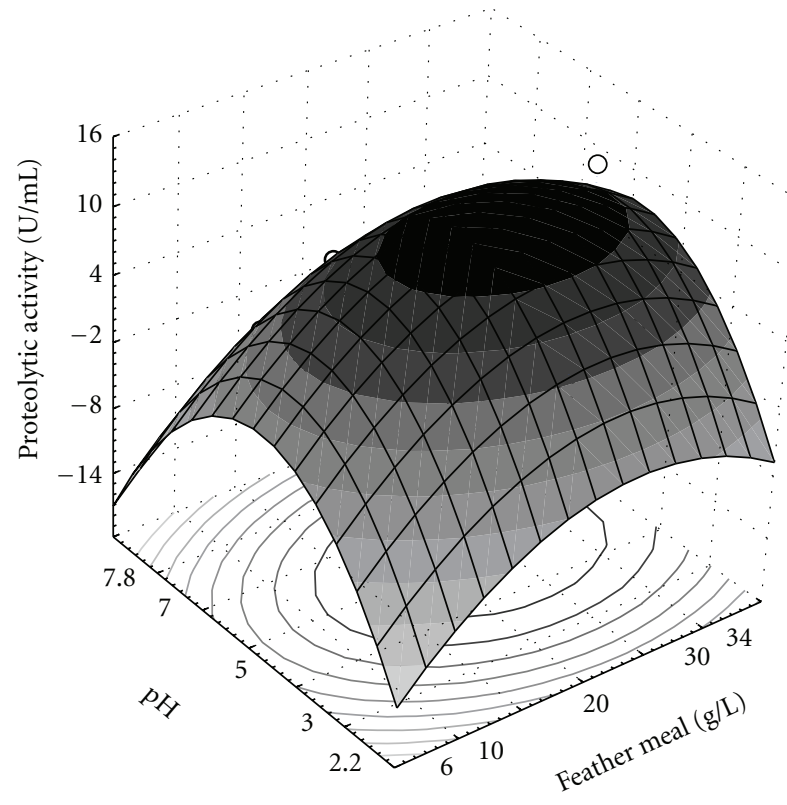

(a)

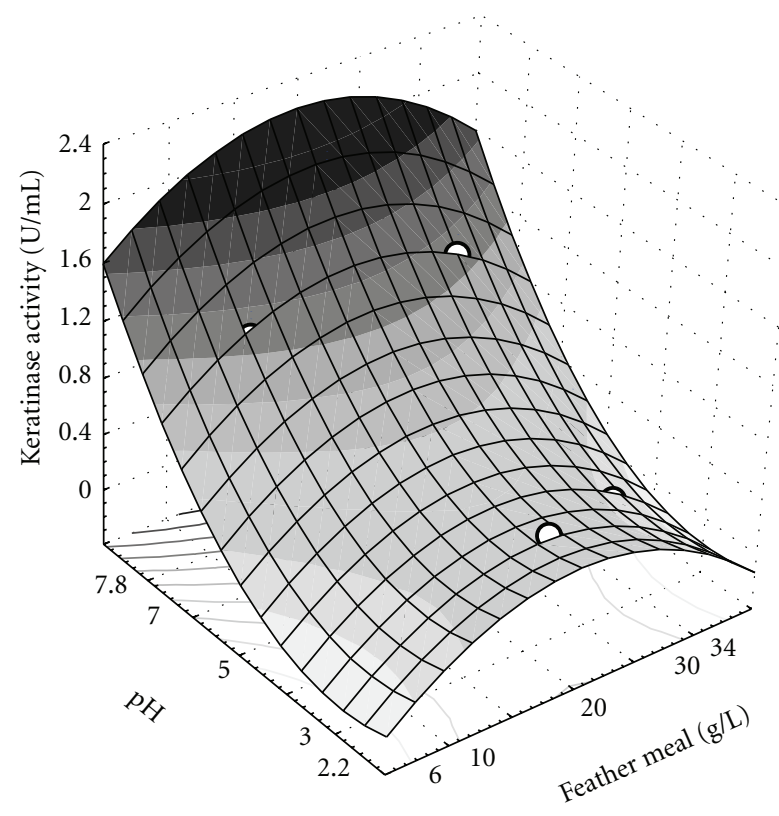

(b)

FIgURE 6: Response surface plots of protease (a) and keratinase (b) production by A. niger as a function of pH and feather meal concentration.

significant for the keratinase production (Table 4). The axial feather meal points were shown to negatively affect enzyme yields. Although acidic initial $\mathrm{pH}$ values were demonstrated to enhance protease production when compared to nearneutrality $\mathrm{pH}$ values (Table 3 ), the opposite was observed for keratinase production, that is, the yield of keratinase tended to be higher at near-neutrality $\mathrm{pH}(\mathrm{pH}$ 7.0-7.8; Table 4). In fact, the initial $\mathrm{pH}$ was the most important variable for keratinase production. The interaction between $\mathrm{pH}$ and feather meal concentration was not significant for both activities.

To construct a second-order model, which can predict the enzymatic activity as a function of the independent variables, the variance analysis (ANOVA) was used to evaluate the model significance. The calculated $F$-value was 33.05 for keratinase and 18.13 for protease, whereas the tabulated $F$-value was 4.76 and 3.18 , respectively. As the calculated $F$-values were higher approximately 7 and 6 times than the tabulated $F$-value, the model is predictive. For biological assays, the calculated $F$-value must be higher than 3 times of tabulated $F$-value; thus, the model is considered predictive and significant [36]. It was possible to generate the surface graphics (Figure 6) through (2) and (3), describing the keratinolytic and proteolytic activities as a function of the independent variables

$$
\begin{gathered}
Y_{\text {keratinase }}=0.70-0.18 x_{1}^{2}+0.48 x_{2}+0.19 x_{2}^{2}, \\
Y_{\text {protease }}=11.02+2.10 x_{1}-2.27 x_{1}^{2}-0.70 x_{2}-4.84 x_{2}^{2} .
\end{gathered}
$$

The values of the keratinase activity obtained in the factorial design were smaller than the cultures without initial $\mathrm{pH}$ adjust. The conditions chosen in the experimental design
TABLe 4: Main effects and interaction analysis for keratinase

\begin{tabular}{|c|c|c|c|c|}
\hline Factors & $\begin{array}{c}\text { Effect } \\
\text { keratinase }\end{array}$ & $\begin{array}{l}\text { Standard } \\
\text { error }\end{array}$ & $t$ value & $P$ value \\
\hline Medium & 0.702720 & 0.063294 & 11.10241 & $0.001566^{*}$ \\
\hline $\begin{array}{l}\text { Feather } \\
\text { meal }(L)\end{array}$ & -0.045272 & 0.089646 & -0.50501 & 0.648314 \\
\hline $\begin{array}{l}\text { Feather } \\
\text { meal }(Q)\end{array}$ & -0.369430 & 0.100496 & -3.67606 & $0.034853^{*}$ \\
\hline $\mathrm{pH}(L)$ & 0.959379 & 0.089646 & 10.70186 & $0.001744^{*}$ \\
\hline $\mathrm{pH}(Q)$ & 0.387574 & 0.100496 & 3.85660 & $0.030803^{*}$ \\
\hline $\begin{array}{l}\text { Feather } \\
\text { meal } \times \mathrm{pH}\end{array}$ & -0.130000 & 0.126590 & -1.02694 & 0.380013 \\
\hline
\end{tabular}
production by $A$. niger growing on feather meal.

$R^{2}=0.93$.

* Significant factors, $P<0.05$.

were more favorable to protease production, obtaining an increase in the proteolytic activity. Nevertheless, the equations obtained in this study could predict the enzymatic activity of each enzyme and could be used to optimize conditions of the bioprocess.

To validate the RSM, four points were chosen, and experimental and predicted enzymatic activities were determined to these points (Table 5). In biological processes, a difference until $20 \%$ between experimental and predicted results is acceptable [37], and as all values are within this range, the model describes adequately the influence of feather meal concentration and $\mathrm{pH}$ on enzyme production.

Feather meal was selected as substrate for protease and keratinase production by $A$. niger. This strain produces an aspartic protease with general proteolytic activity and 
TABLE 5: Experiments for model validation.*

\begin{tabular}{lccccc}
\hline & & \multicolumn{4}{c}{ Enzymatic activity } \\
\multicolumn{2}{c}{$\begin{array}{c}\text { Run** } \\
\text { Feather } \\
\text { meal (g/L) }\end{array}$} & pH & Experimental & Predicted & Difference (\%) \\
\hline 1 & 26 & 6.2 & 1.01 & 0.99 & 1.99 \\
& & & 9.03 & 10.94 & 17.46 \\
2 & \multirow{2}{*}{30} & 6.2 & 0.97 & 0.88 & 9.28 \\
& & & 7.92 & 8.69 & 8.86 \\
3 & 26 & 5.0 & 0.55 & 0.63 & 13.00 \\
& & & 11.04 & 11.46 & 3.66 \\
4 & \multirow{2}{*}{26} & 9.0 & 2.59 & 2.35 & 10.21 \\
& & & 0 & -9.30 & 0 \\
\hline
\end{tabular}

${ }^{*}$ Models for keratinase and protease production are represented by (2) and (3), respectively (see text).

**The first line for each run shows the keratinolytic activity and the second line the proteolytic activity.

a serine protease with keratinolytic activity. The optima conditions were different for the production of each enzyme, and the models were validated and can predict the enzymatic activity. A. niger has potential to be used in biotechnological process involving keratin hydrolysis, mainly because of the GRAS status of these products. Thus, more studies are necessary to better exploit this keratinolytic potential.

\section{Acknowledgments}

This work was supported by CNPq, Brazil. Thanks are due to Dr. Patricia Valente da Silva for the help in the choice of primers used in fungus identification and Dr. Charley Christian Staats for the hopeful review of the paper.

\section{References}

[1] A. H. F. J. Roth and P. Dersch, "A novel expression system for intracellular production and purification of recombinant affinity-tagged proteins in Aspergillus niger," Applied Microbiology and Biotechnology, vol. 86, no. 2, pp. 659-670, 2010.

[2] E. Schuster, N. Dunn-Coleman, J. Frisvad, and P. van Dijck, "On the safety of Aspergillus niger-a review," Applied Microbiology and Biotechnology, vol. 59, no. 4-5, pp. 426-435, 2002.

[3] P. W. M. van Dijck, G. C. M. Selten, and R. A. Hempenius, "On the safety of a new generation of DSM Aspergillus niger enzyme production strains," Regulatory Toxicology and Pharmacology, vol. 38, no. 1, pp. 27-35, 2003.

[4] G. Jarai and F. Buxton, "Nitrogen, carbon, and $\mathrm{pH}$ regulation of extracellular acidic proteases of Aspergillus niger," Current Genetics, vol. 26, no. 3, pp. 238-244, 1994.

[5] K. S. Vishwanatha, A. G. Appu Rao, and S. A. Singh, "Characterisation of acid protease expressed from Aspergillus oryzae MTCC 5341," Food Chemistry, vol. 114, no. 2, pp. 402-407, 2009.

[6] C. Vignardet, Y. C. Guillaume, L. Michel, J. Friedrich, and J. Millet, "Comparison of two hard keratinous substrates submitted to the action of a keratinase using an experimental design," International Journal of Pharmaceutics, vol. 224, no. 1-2, pp. 115-122, 2001.
[7] R. C. S. Thys, F. S. Lucas, A. Riffel, P. Heeb, and A. Brandelli, "Characterization of a protease of a feather-degrading Microbacterium species," Letters in Applied Microbiology, vol. 39, no. 2, pp. 181-186, 2004.

[8] R. D. B. Fraser and D. A. D. Parry, "Molecular packing in the feather keratin filament," Journal of Structural Biology, vol. 162, no. 1, pp. 1-13, 2008.

[9] L. Kreplak, J. Doucet, P. Dumas, and F. Briki, "New aspects of the $\alpha$-helix to $\beta$-sheet transition in stretched hard $\alpha$-keratin fibers," Biophysical Journal, vol. 87, no. 1, pp. 640-647, 2004.

[10] A. Brandelli, "Bacterial keratinases: useful enzymes for bioprocessing agroindustrial wastes and beyond," Food and Bioprocess Technology, vol. 1, no. 2, pp. 105-116, 2008.

[11] R. Gupta and P. Ramnani, "Microbial keratinases and their prospective applications: an overview," Applied Microbiology and Biotechnology, vol. 70, no. 1, pp. 21-33, 2006.

[12] S. T. Silveira, D. J. Daroit, and A. Brandelli, "Pigment production by Monascus purpureus in grape waste using factorial design," LWT_Food Science and Technology, vol. 41, no. 1, pp. 170-174, 2008.

[13] S. Zhu, S. Lee, S. K. Hargrove, and G. Chen, "Prediction of combustion efficiency of chicken litter using an artificial neural network approach," Fuel, vol. 86, no. 5-6, pp. 877-886, 2007.

[14] A. K. Casali, L. Goulart, L. K. Rosa e Silva et al., "Molecular typing of clinical and environmental Cryptococcus neoformans isolates in the Brazilian state Rio Grande do Sul," FEMS Yeast Research, vol. 3, no. 4, pp. 405-415, 2003.

[15] S. Horisawa, Y. Sakuma, and S. Doi, "Qualitative and quantitative PCR methods using species-specific primer for detection and identification of wood rot fungi," Journal of Wood Science, vol. 55, no. 2, pp. 133-138, 2009.

[16] M. A. Larkin, G. Blackshields, N. P. Brown et al., "Clustal W and Clustal X version 2.0," Bioinformatics, vol. 23, no. 21, pp. 2947-2948, 2007.

[17] K. Tamura, J. Dudley, M. Nei, and S. Kumar, "MEGA4: molecular evolutionary genetics analysis (MEGA) software version 4.0," Molecular Biology and Evolution, vol. 24, no. 8, pp. 1596-1599, 2007.

[18] L. A. Dedavid e Silva, F. C. Lopes, S. T. Silveira, and A. Brandelli, "Production of cellulolytic enzymes by Aspergillus phoenicis in grape waste using response surface methodology," Applied Biochemistry and Biotechnology, vol. 152, no. 2, pp. 295-305, 2009.

[19] AOAC, Official Methods of Analysis, Association of Official Analytical Chemists, Washington, DC, USA, 15th edition, 2005.

[20] M. P. Sangorrín, E. J. Folco, C. M. Martone, and J. J. Sánchez, "Purification and characterization of a proteinase inhibitor from white croaker skeletal muscle (Micropogon opercularis)," International Journal of Biochemistry and Cell Biology, vol. 33, no. 7, pp. 691-699, 2001.

[21] A. Riffel, S. Ortolan, and A. Brandelli, "De-hairing activity of extracellular proteases produced by keratinolytic bacteria," Journal of Chemical Technology and Biotechnology, vol. 78, no. 8, pp. 855-859, 2003.

[22] A. P. F. Corrêa, D. J. Daroit, and A. Brandelli, "Characterization of a keratinase produced by Bacillus sp. P7 isolated from an Amazonian environment," International Biodeterioration and Biodegradation, vol. 64, no. 1, pp. 1-6, 2010.

[23] R. Myers and R. C. Montgomery, Response Surface Methodology: Process and Product Optimizationusing Designed Experiments, Wiley, New York, NY, USA, 2002. 
[24] J. I. Pitt and A. D. Hocking, "Aspergillus and related Teleomorphs," Fungi and Food Spoilage, Springer Science + Business Media, London, UK, 2009.

[25] F. Giraud, J. Dupont, M. Haon et al., "Phylogenetic analysis of the Aspergillus niger aggregate in relation to feruloyl esterase activity," Research in Microbiology, vol. 158, no. 5, pp. 413-419, 2007.

[26] E. R. Palencia, M. A. Klich, A. E. Glenn, and C. W. Bacon, "Use of a rep-PCR system to predict species in the Aspergillus section Nigri," Journal of Microbiological Methods, vol. 79, no. 1, pp. 1-7, 2009.

[27] G. Perrone, A. Susca, F. Epifani, and G. Mulè, "AFLP characterization of Southern Europe population of Aspergillus section Nigri from grapes," International Journal of Food Microbiology, vol. 111, pp. S22-S27, 2006.

[28] A. R. El Boushy, A. F. B. van der Poel, and O. E. D. Walraven, "Feather meal - a biological waste: its processing and utilization as a feedstuff for poultry," Biological Wastes, vol. 32, no. 1, pp. 39-74, 1990.

[29] A. Grazziotin, F. A. Pimentel, E. V. de Jong, and A. Brandelli, "Nutritional improvement of feather protein by treatment with microbial keratinase," Animal Feed Science and Technology, vol. 126, no. 1-2, pp. 135-144, 2006.

[30] P. Anbu, S. C. B. Gopinath, A. Hilda, N. Mathivanan, and G. Annadurai, "Secretion of keratinolytic enzymes and keratinolysis by Scopulariopsis brevicaulis and Trichophyton mentagrophytes: regression analysis," Canadian Journal of Microbiology, vol. 52, no. 11, pp. 1060-1069, 2006.

[31] A. Brandelli, D. J. Daroit, and A. Riffel, "Biochemical features of microbial keratinases and their production and applications," Applied Microbiology and Biotechnology, vol. 85, no. 6, pp. 1735-1750, 2010.

[32] R. Siala, A. Sellami-Kamoun, M. Hajji, I. Abid, N. Gharsallah, and M. Nasri, "Extracellular acid protease from Aspergillus niger I1: purification and characterization," African Journal of Biotechnology, vol. 8, no. 18, pp. 4582-4589, 2009.

[33] F. M. Olajuyigbe, J. O. Ajele, and T. L. Olawoye, "Some physicochemical properties of acid protease produced during growth of Aspergillus niger (NRRL 1785)," Global Journal of Pure and Applied Sciences, vol. 9, pp. 523-528, 2003.

[34] A. M. Farag and M. A. Hassan, "Purification, characterization and immobilization of a keratinase from Aspergillus oryzae," Enzyme and Microbial Technology, vol. 34, no. 2, pp. 85-93, 2004.

[35] P. D. Haaland, Experimental Design in Biotechnology, Marcel Dekker, New York, NY, USA, 1989.

[36] R. M. D. B. Santos, A. A. P. Firmino, C. M. De Sá, and C. R. Felix, "Keratinolytic activity of Aspergillus fumigatus fresenius," Current Microbiology, vol. 33, no. 6, pp. 364-370, 1996.

[37] K. R. Kiran, N. G. Karanth, and S. Divakar, "Preparation of stearoyl lactic acid ester catalyzed by lipases from Rhizomucor miehei and porcine pancreas optimization using response surface methodology," Applied Microbiology and Biotechnology, vol. 52, no. 4, pp. 579-584, 1999. 

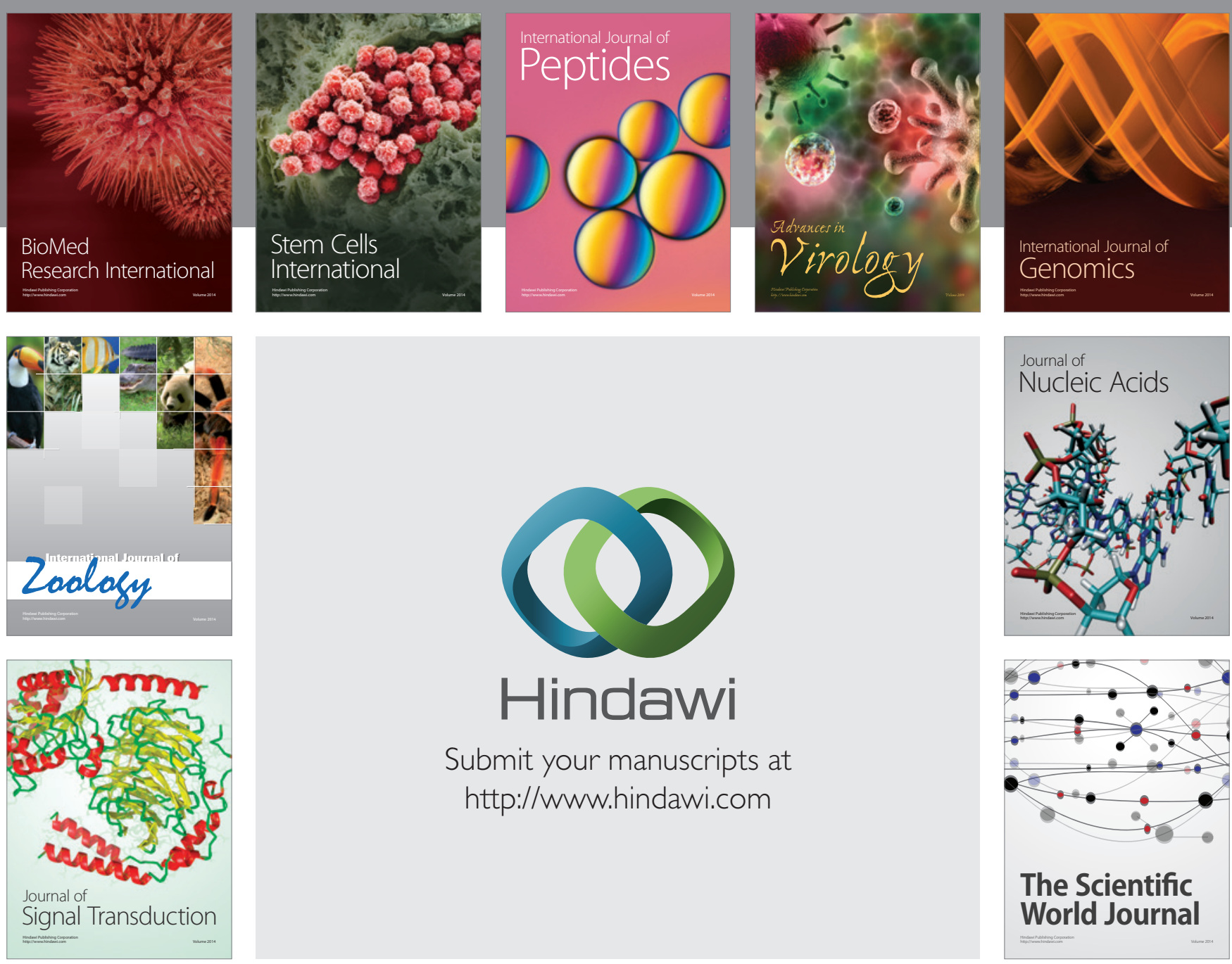

Submit your manuscripts at

http://www.hindawi.com
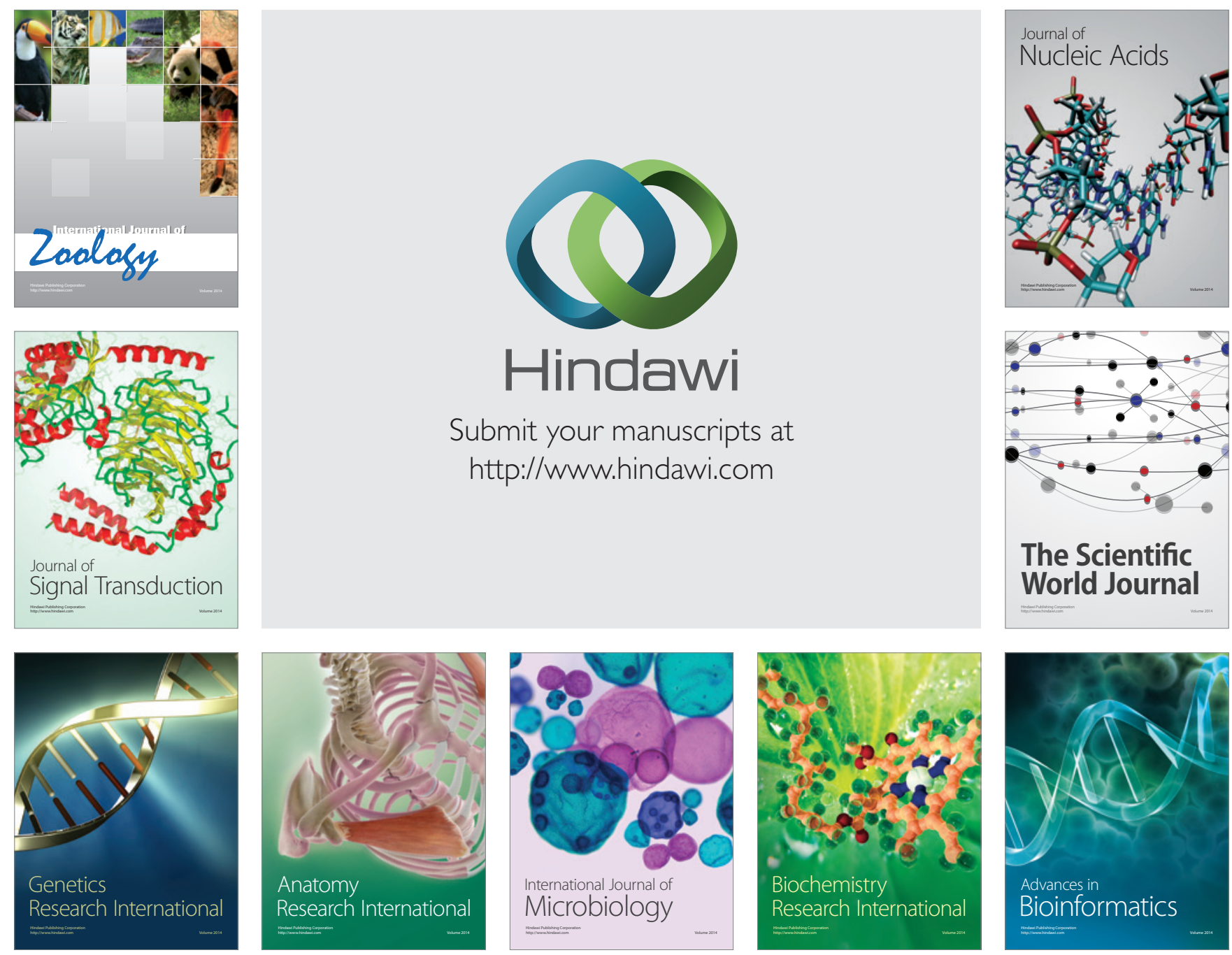

The Scientific World Journal
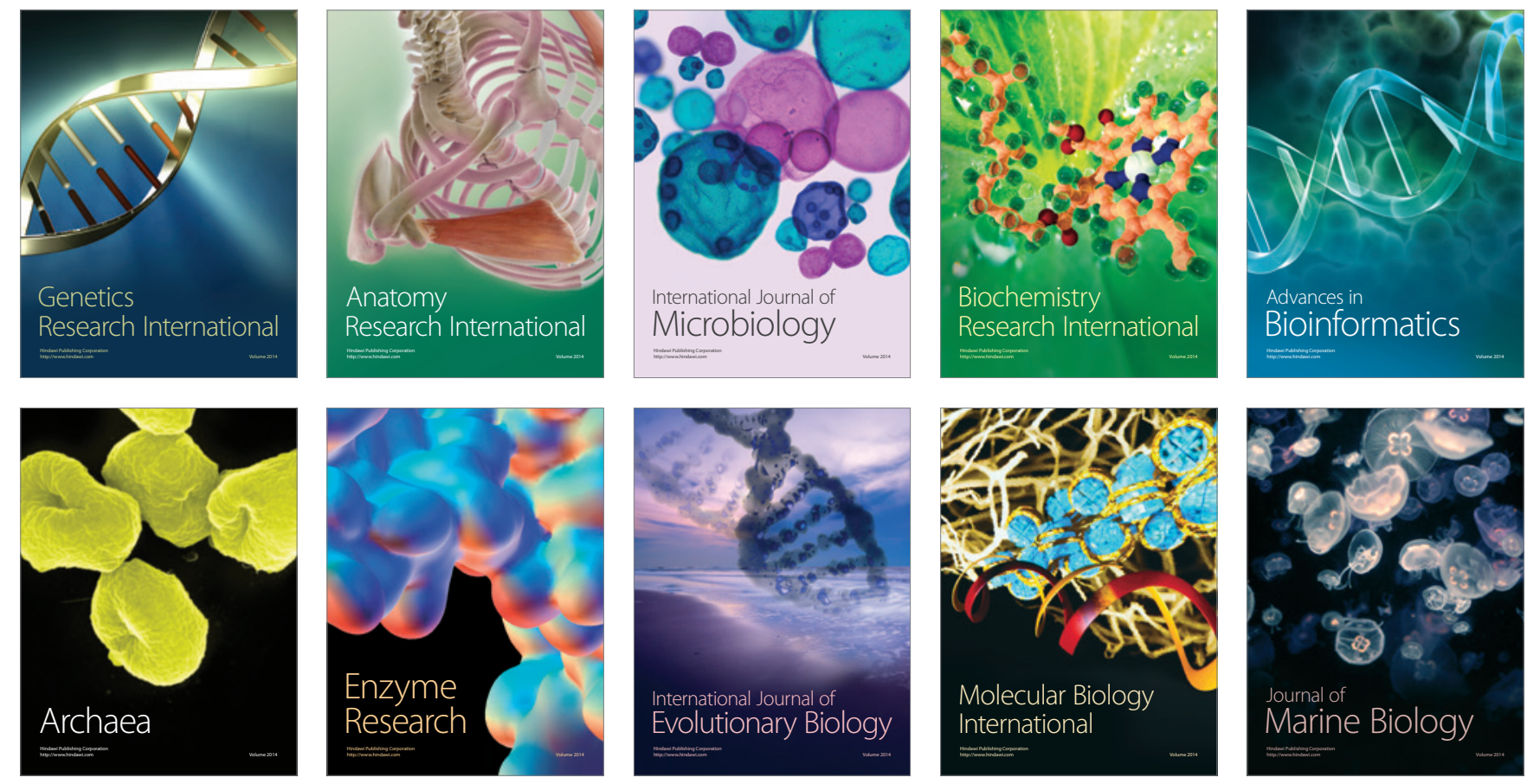